\title{
Development of a child's visual thinking by the means of original children's animation
}

\author{
Sergey Averin ${ }^{1,2}$, Svetlana Karpova $^{3}$, Natalia Murodhodjaeva ${ }^{3 *}$, Tatiana Savenkova ${ }^{3}$, and \\ Olga Tsaplina ${ }^{4}$ \\ ${ }^{1}$ Moscow City University, Institute of Humanities, Department of Teaching Methods of History, \\ Social Studies and Law, Moscow, Russia \\ ${ }^{2}$ ELTI-KUDITS Ltd, Moscow, Russia \\ ${ }^{3}$ Moscow City University, Institute of Pedagogy and Psychology of Education, Department of \\ Pedagogy, Moscow, Russia \\ ${ }^{4}$ Moscow City University, Institute of Pedagogy and Psychology of Education, Department of \\ Psychology, Moscow, Russia
}

\begin{abstract}
The modern sociocultural situation causes the need to use distance learning technologies even at the level of preschool education, as well as the increased use of information technologies as a means of working with preschool students. The goal of the present article resides not in the analysis of the positive and negative aspects of information technologies in preschool education but the search for and the substantiation of the mechanism of their effective implementation. One of the most effective mechanisms is presented by the technique of original children's animation. The potential effectiveness of the indicated process is examined in the context of the development of children's visual thinking. Thus, the article presents the authors' attempt to substantiate the development of the method of original children's animation determining the development of children's visual thinking accounting for the requirements of modern information society and to propose specific recommendations for the software of a children's animation studio. The set goal is achieved using the methods of content analysis, the methods of comparative analysis of scientific and methodological materials and system analysis, the method of mathematical and statistical data processing, expert assessment, and generalization of study results. Based on the study results, an educational module "I CREATE THE WORLD Animation Studio" is developed and introduced into the practice of preschool pedagogics as a potentially effective instrument for the development of visual thinking and recommendations for the software of a children's animation studio in a kindergarten are proposed.
\end{abstract}

Keywords: information technologies in education, visual thinking, original animation, preschool age.

\footnotetext{
* Corresponding author: murodhodjaeva@yandex.ru
} 


\section{Introduction}

Information and computer technologies are an integral part of the life of a modern child. In some families, parents strive to protect children from the active use of smartphones, tablets, laptops, and computers believing that gadgets have a negative impact on the physical and mental state of children $[1,2]$. This statement is merely a statement of fact since diving into the controversy of the harm and benefits of technology will inevitably lead to the exchange of theses and antitheses rather than actual solutions. The present article focuses on a reasoned presentation of a theoretical model and practice of realizing the potential of information technologies in the education of preschool children that allow to not only reconcile the adult opponents and supporters of said technologies but also achieve the most important goal - use technology for the benefit of children's development [3].

Designing a method of original children's animation presents a scientific and methodical response to the informational challenges in the sphere of preschool education. The goal of the present study is to provide a scientific and methodical substantiation and empirical verification of the effectiveness of the method of original children's animation for the development of visual thinking in preschool children.

The innovative work that has been carried out in preschool departments of the State Budgetary Educational Institution "School 2103" in the city of Moscow and the State Budgetary Educational Institution Preschool Child Development Center No. 14 in the city of Reutov since 2016 allowed developing and implementing the technology of original children's animation in over 350 preschool educational organizations of Russia and Kazakhstan, designing the necessary equipment, selecting the suitable animation software, and formulating specific recommendations for new animation software that would have the necessary potential for the development of visual thinking and remain understandable for children at the same time. The created original children's animation method is included in the structure of the "I CREATE THE WORLD Animation Studio" module. The very idea of such modules is implemented in the partial program of the Institute for the Study of Childhood, Family, and Education of the Russian Academy of Education "STEM Education of Preschool and Primary School Children" (under the scientific supervision of T.V. Volosovets, S.A. Averina, and V.A. Markova) [4].

\section{Methods. Theoretical foundations. Visual thinking}

Visual thinking is understood by us as a specific system of various ways of visual solutions of multidirectional tasks. A distinguishing characteristic of visual thinking is the visual representation of conditions and interaction with the images constituting them without performing practical actions in reality [5].

Visual thinking primarily operates with models and images: they present the initial material and the operational unit of direct sensory perception of the real world. Visual thinking is quite a complex formation. It presents a certain system of dissimilar elements that are harmoniously interconnected. Within visual thinking, three main processes of thinking are typically distinguished: the first process involves the creation of an image, the second one concerns the ability to operate with this image, and the third one comprises orientation in the real or imagined environment $[6,7]$. 


\section{Results. The system for diagnosing visual thinking development levels in preschoolers}

The methods used for the assessment of the level of visual thinking development in preschoolers included well-known methods developed by R.I. Bardina, O.M. Diachenko, A.F. Luriia, and R.S. Nemov (Table 1). An important parameter considered in the selection of these methods was the possibility of their implementation by teachers lacking special psychological education.

Table 1. The system for diagnosing visual thinking development levels in preschoolers.

\begin{tabular}{|c|c|c|c|}
\hline $\begin{array}{c}\text { Visual thinking } \\
\text { development } \\
\text { criteria }\end{array}$ & $\begin{array}{c}\text { Visual thinking development } \\
\text { indicator }\end{array}$ & Assessment method & $\begin{array}{c}\text { The } \\
\text { author of } \\
\text { the } \\
\text { method }\end{array}$ \\
\hline $\begin{array}{l}\text { Visual analysis } \\
\text { and synthesis }\end{array}$ & $\begin{array}{l}\text { Studying the level of visual } \\
\text { thinking development }\end{array}$ & $\begin{array}{l}\text { "What objects are } \\
\text { hidden in the } \\
\text { drawings?" }\end{array}$ & $\begin{array}{l}\text { R.S. } \\
\text { Nemov }\end{array}$ \\
\hline Orientation actions & $\begin{array}{l}\text { Studying the ability to use } \\
\text { schematic images for } \\
\text { orientation in space }\end{array}$ & $\begin{array}{l}\text { "Schematization" } \\
\text { (Labyrinth) }\end{array}$ & $\begin{array}{c}\text { R.I. } \\
\text { Bardina }\end{array}$ \\
\hline Visual coding & $\begin{array}{l}\text { Studying the ability to translate } \\
\text { a text into the sign and symbolic } \\
\text { language (coding) }\end{array}$ & "Pictogram" & A.F. Luriia \\
\hline $\begin{array}{l}\text { Correlation of the } \\
\text { scheme and the } \\
\text { real situation }\end{array}$ & $\begin{array}{l}\text { Diagnosing the level of } \\
\text { development of perception and } \\
\text { the correlation of the shape of } \\
\text { objects with the presented } \\
\text { samples (standards) }\end{array}$ & "Etalons" & $\begin{array}{c}\text { O.M. } \\
\text { Diachenko }\end{array}$ \\
\hline
\end{tabular}

The pilot study was conducted based on preschool departments of schools No. 883, 1210, 1216, 1430, and 1523 in Moscow. The ascertaining experiment involved 123 senior preschool children at an average age of 6 years and 2 months old. The overall development of children lies within the norm and no delays in mental and speech development were discovered, thus, the formed sample meets the requirements of representativeness and homogeneity. A method of a random selection of natural groups was used. These educational institutions selected for the study do not practice any special procedures in the process of accepting children in a preschool organization, therefore, there is a random sample of children from families that are generally different but similar in social status which allows us to obtain objective scientific data.

The results of the pilot study presented in Figure 1 and Tables 2-5 indicate that when the above-mentioned criteria were rated on a five-point scale, the highest mean value of 4.15 was found in the criterion of correlation of the scheme and the real situation (the "Etalons" method, O.M. Diachenko). Average values were detected in the abilities to conduct visual analysis (3.34 points) and orientation actions (3.89 points). The lowest scores are observed in the criteria of visual coding (3.16; the "Pictogram" method, A.F. Luriia) and visual analysis (3.05; the "What objects are hidden in the drawings?" method by R.S. Nemov). 
Correlation of the scheme and the real situation

\section{Visual coding \\ Orientation actions \\ Visual synthesis \\ Visual analysis}

0

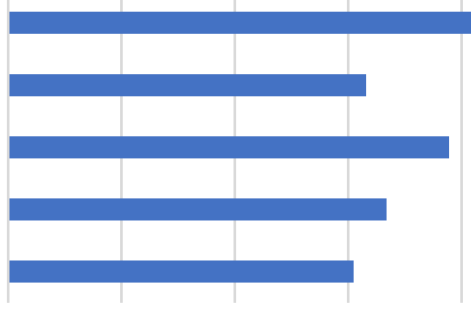

1

2

4

Fig. 1. Results of diagnostics of the visual thinking development levels in older preschoolers.

Table 2. Mean values of the development of visual thinking in older preschoolers

\begin{tabular}{|c|c|}
\hline Visual thinking development criteria & Mean \\
\hline Visual analysis & 3.05 \\
\hline Visual synthesis & 3.34 \\
\hline Orientation actions & 3.89 \\
\hline Visual coding & 3.16 \\
\hline Correlation of the scheme and the real situation & 4.15 \\
\hline
\end{tabular}

Table 3. Descriptive statistics of visual thinking development criteria in older preschoolers

\begin{tabular}{|c|c|c|c|c|c|}
\hline Indicators & Min. & Max. & Mean & SD & Variance \\
\hline Age & 5.0 & 7.3 & 6.211 & .6000 & .360 \\
\hline Visual analysis & 1 & 5 & 3.05 & .952 & .907 \\
\hline Visual synthesis & 1 & 5 & 3.34 & 1.001 & 1.002 \\
\hline Labyrinth & 1 & 5 & 3.89 & 1.112 & 1.236 \\
\hline Pictogram & 1 & 5 & 3.16 & .754 & .568 \\
\hline Etalons & 1 & 5 & 4.15 & 1.050 & 1.102 \\
\hline
\end{tabular}

Assessment of standard deviation and variance supports the obtained mean values of the criteria of visual thinking development in older preschoolers.

Table 4. Group statistics for the criteria of visual thinking development in older preschoolers

\begin{tabular}{|c|c|c|c|c|c|c|}
\hline Indicators & Sex & Mean & SD & SE & t & Significance \\
\hline Visual analysis & $\mathrm{M}$ & 3.06 & .998 & .124 & .152 & .879 \\
\cline { 2 - 7 } & $\mathrm{F}$ & 3.04 & .906 & .120 & & \\
\hline \multirow{2}{*}{ Visual synthesis } & $\mathrm{M}$ & 3.29 & 1.086 & .135 & -.514 & .608 \\
\cline { 2 - 7 } & $\mathrm{F}$ & 3.39 & .901 & .119 & & \\
\hline \multirow{2}{*}{ Labyrinth } & $\mathrm{M}$ & 3.91 & 1.234 & .153 & .151 & .881 \\
\cline { 2 - 7 } & $\mathrm{F}$ & 3.88 & .965 & .128 & & \\
\hline \multirow{2}{*}{ Pictogram } & $\mathrm{M}$ & 3.15 & .690 & .086 & -.157 & .875 \\
\cline { 2 - 7 } & $\mathrm{F}$ & 3.18 & .826 & .109 & & \\
\hline \multirow{2}{*}{ Etalons } & $\mathrm{M}$ & 4.17 & 1.009 & .125 & .243 & .809 \\
\cline { 2 - 7 } & $\mathrm{F}$ & 4.12 & 1.103 & .146 & & \\
\hline
\end{tabular}

In the evaluation of group statistics for the criteria of visual thinking development in older preschoolers, no significant differences were found between the indicators in the group of boys and the group of girls. Correlation analysis of the development of visual thinking in older preschoolers demonstrated a minor relationship between the level of development of visual analysis and orientation actions, as well as between visual coding and correlation of the scheme and the real situation. A slight correlation was also discovered between the level of development of orientation actions and visual coding. 
Therefore, the pilot study shows that the children possess a well-developed ability to correlate a scheme with the real situation and carry out orientation actions. Meanwhile, the ability to execute visual coding and visual analysis is developed at an average level in modern children.

\section{Discussion. The potential of information technologies as a means of developing a child's visual thinking}

The potential of information technologies in the development of a preschool child is realized by us through our method of original children's animation based on using an animation studio [8]. Work in an animation studio as an example of the implementation of information and computer technologies in preschool education has great potential for the development of visual thinking, particularly for the development of visual coding and visual analysis which can be considered the "problem areas" based on the results of the conducted pilot study [912].

We have developed over 80 game tasks contributing to the development of visual thinking, for example, tasks of the following types:

- Making a mini-cartoon with children about how a ball rolls and how a cube can move. The story about the ball and the cube shapes can be based on the "Kolobok" fairy tale the main character of which has to be rolling around.

- Preparing scripts for small cartoons with characters reflecting different sensory standards. For example, how three balls of different sizes turn into a snowman, how flowers of different colors bloom, etc.

Filming a small cartoon in which objects appear and disappear to show it to children and stimulate them to comment whether there is "one", "none", or "many" objects present. For example, there may be a different number of frogs in a lake - "one", "many", or "none" when they all jump into the water and disappear from view.

\section{Conclusion}

Therefore, the scientific and methodical response to informational challenges in the sphere of preschool education is presented by the design of the method of original children's animation based on using an animation studio and affecting the development of preschoolers' visual thinking [13].

Speech plays an important role in the development of a child's visual thinking. A preschooler has mastery over the dialogic and monologic forms of speech and possesses a developed phonemic hearing. Therefore, increased value is presented by the opportunity to record the voices of children making a cartoon voice-over while viewing the project in realtime. There have to be functions of uploading music and other audio files from a computer, mark the beginning and the end of a fragment ("cut"), move an audio fragment by frames, and "paste" fragments. It is desirable that the attachment of an audio track can be seen in the ruler or column with frames allowing to accurately bind the beginning and the end of the corresponding audio fragment to a specific frame. The presence of a sound library or an audio library containing background music, the sounds of nature, laughter, beats, as well as various sound effects that could be used in original animations, is also highly recommended.

Therefore, animation software has to be designed as simple and user-friendly as possible $[4,15]$. There is no need to overload the functionality of such a program since the main goal lies not in creating a high-quality and complex cartoon (which is the prerogative of professionals) but in the possibility of the program being used by preschoolers and their teachers with a guaranteed result. 


\section{References}

1. E.S. Kurakina, E.A. Alisov, Tambov University Review. Series: Humanities, 22(3(167)), 33-38 (2017). https://doi.org/10.20310/1810-0201-2017-22-3(166)-33-38

2. S.A. Shinde, P.R. Rajeswari, International Journal of Engineering and Technology (UAE), 7(3), 1019-1023 (2018). https://doi.org/10.14419/ijet.v7i3.12654

3. N.S. Murodhodjaeva, A.V. Madumarova, Ispolzovanie informatsionnokommunikatsionnykh tekhnologii v protsesse intellektualnogo razvitiia detei doshkolnogo vozrasta [The use of information and communication technologies in the process of intellectual development of preschool children], in Informatizatsiia obrazovaniia: teoriia i praktika: sbornik materialov mezhdunarodnoi nauchnoprakticheskoi konferentsii, 20-21 November 2015, Omsk, Russia, 110-112 (2015)

4. T.V. Volosovets, V.A. Markova, S.A. Averin, STEM-obrazovanie detei doshkolnogo i mladshego shkolnogo vozrasta. Partsialnaia modulnaia programma razvitiia intellektualnykh sposobnostei $\mathrm{v}$ protsesse poznavatelnoi deiatelnosti i vovlecheniia $\mathrm{V}$ nauchno-tekhnicheskoe tvorchestvo: uchebnaia programma [STEM education for preschool and primary school children. Partial modular program for the development of intellectual abilities in the process of cognitive activity and involvement in scientific and technical creativity: curriculum] (BINOM. Laboratoriia znanii, Moscow, 2018)

5. I.S. Iakimanskaia (Ed.), Vozrastnye i individualnye osobennosti obraznogo myshleniia uchashchikhsia [Age and individual characteristics of students' visual thinking] (Pedagogika, Moscow, 1989)

6. V.V. Ilichev, E.V. Ilicheva, Pedagogika i sovremennost, 1, 2-4 (2013)

7. A.I. Savenkov, Elektronnoe prakticheskoe prilozhenie k zhurnalu "Sovremennoe doshkolnoe obrazovanie”, 6, 6-10 (2019). Accessed on: December 16, 2020. [Online]. Available: https://sdo-journal.ru/journalpril/aisavenkov-predstavleniya-o-detskojodaryonnosti-kak-psihicheskom-yavlenii-v-sovremennoj-obrazovatelnoj-praktike.html

8. J.C. Wright, A.C. Huston, R.P. Ross, S.L. Calvert, D. Rolandelli, L.A. Weeks, P. Raeissi, R. Potts, Developmental Psychology, 20(4), 653-666 (1984). https://doi.org/10.1037/0012-1649.20.4.653

9. R.J. Daker, R.A. Cortes, I.M. Lyons, A.E. Green, Journal of Experimental Psychology: General, 149(1), 42-57 (2020). https://doi.org/10.1037/xge0000630

10. D.E. Delany, C.S. Cheung, Psychology of Aesthetics, Creativity, and the Arts, 14(4), 462-474 (2019). https://doi.org/10.1037/aca0000266

11. S.K.C. Dygert, A.F. Jarosz, Journal of Experimental Psychology: General, 149(7), 1249-1274 (2020). https://doi.org/10.1037/xge0000713

12. J. Guegan, C. Brechet, J. Nelson, Journal of Media Psychology: Theories, Methods, and Applications (to be published) (2020). https://doi.org/10.1027/1864-1105/a000279

13. X. Wang, American Educational Research Journal, 50(5), 1081-1121 (2013). https://doi.org/10.3102/0002831213488622

14. J.M. Breiner, S.S. Harkness, C.C. Johnson, C.M. Koehler, School Science and Mathematics, 112(1), 3-11 (2012). https://doi.org/10.1111/j.1949-8594.2011.00109.x

15. A.V. Maltese, C.S. Melki, H.L. Wiebke, Science Education, 98(6), 937-962 (2014). https://doi.org/10.1002/sce.21132 